\title{
Eddy covariance carbonyl sulfide flux measurements with a quantum cascade laser absorption spectrometer
}

\author{
Katharina Gerdel, Felix Maximilian Spielmann, Albin Hammerle, and Georg Wohlfahrt \\ Institut of Ecology, University of Innsbruck, Innsbruck, Austria \\ Correspondence to: Georg Wohlfahrt (georg.wohlfahrt@uibk.ac.at)
}

Received: 23 September 2016 - Discussion started: 28 October 2016

Revised: 23 August 2017 - Accepted: 24 August 2017 - Published: 26 September 2017

\begin{abstract}
The trace gas carbonyl sulfide (COS) has lately received growing interest from the eddy covariance (EC) community due to its potential to serve as an independent approach for constraining gross primary production and canopy stomatal conductance. Thanks to recent developments of fast-response high-precision trace gas analysers (e.g. quantum cascade laser absorption spectrometers, QCLAS), a handful of EC COS flux measurements have been published since 2013. To date, however, a thorough methodological characterisation of QCLAS with regard to the requirements of the EC technique and the necessary processing steps has not been conducted. The objective of this study is to present a detailed characterisation of the COS measurement with the Aerodyne QCLAS in the context of the EC technique and to recommend best EC processing practices for those measurements. Data were collected from May to October 2015 at a temperate mountain grassland in Tyrol, Austria. Analysis of the Allan variance of high-frequency concentration measurements revealed the occurrence of sensor drift under field conditions after an averaging time of around $50 \mathrm{~s}$. We thus explored the use of two high-pass filtering approaches (linear detrending and recursive filtering) as opposed to block averaging and linear interpolation of regular background measurements for covariance computation. Experimental lowpass filtering correction factors were derived from a detailed cospectral analysis. The $\mathrm{CO}_{2}$ and $\mathrm{H}_{2} \mathrm{O}$ flux measurements obtained with the QCLAS were compared with those obtained with a closed-path infrared gas analyser. Overall, our results suggest small, but systematic differences between the various high-pass filtering scenarios with regard to the fraction of data retained in the quality control and flux magnitudes. When $\mathrm{COS}$ and $\mathrm{CO}_{2}$ fluxes are combined in the ecosystem relative uptake rate, systematic differences be-
\end{abstract}

tween the high-pass filtering scenarios largely cancel out, suggesting that this relative metric represents a robust key parameter comparable between studies relying on different post-processing schemes.

\section{Introduction}

The need to understand human-induced climate change and in this context to understand the pathways and processes determining the global carbon cycle dynamics, triggered the increased use of the eddy covariance (EC) method for carbon dioxide $\left(\mathrm{CO}_{2}\right)$ flux measurements and resulted in the establishment of the first flux measurement network, the EUROFLUX project, in 1996. Today, the EC method is routinely used for measurements of the energy and trace gas exchange between the atmosphere and the biosphere at $>500$ sites within the FLUXNET project (Baldocchi, 2003, 2014), mainly focusing on the exchange processes of $\mathrm{CO}_{2}$ and $\mathrm{H}_{2} \mathrm{O}$.

By partitioning the biosphere-atmosphere $\mathrm{CO}_{2}$ fluxes (net ecosystem exchange - NEE) into uptake (gross primary productivity - GPP) and release (ecosystem respiration $-R_{\text {eco }}$ ), it is possible to quantify the two main processes underlying the NEE. To this end, eddy covariance $\mathrm{CO}_{2}$ flux partitioning algorithms are used. They exploit the strong contrast between night-time release and daytime net uptake of $\mathrm{CO}_{2}$ (Reichstein et al., 2005; Lasslop et al., 2010), based on the extrapolation of night-time $R_{\text {eco }}$ to daytime conditions. The fact that the theoretical models underlying the flux partitioning algorithms are highly simplistic and thus neglect or misinterpret certain processes has caused considerable criticism (Wohlfahrt et al., 2005b; Wohlfahrt and Gu, 2015; Wohlfahrt and Galvagno, 2017). However, to date the resulting GPP 
and $R_{\text {eco }}$ estimates represent the major source of data-driven assessments of the terrestrial carbon cycle (e.g. Beer et al., 2010; Mahecha et al., 2010) and the calibration of carbon cycle models (e.g. Friend et al., 2007).

Carbonyl sulfide (COS or OCS), a trace gas present in the atmosphere with an average mole fraction of $500 \mathrm{ppt}$, shares a similar pathway during leaf uptake as $\mathrm{CO}_{2}$ with the important difference that no "respiration-like" process, i.e. emission of COS from leaves, has been reported. This codiffusion with $\mathrm{CO}_{2}$ and the one-way direction of the flux into the land biosphere (Asaf et al., 2013) have been suggested to offer the possibility of using COS as a proxy of gross primary productivity (Seibt et al., 2010; Blonquist Jr. et al., 2011), even though bidirectional exchange by soils complicates matters (e.g. Kitz et al., 2017). Ecosystem-atmosphere COS flux measurements were, up to very recently, limited by the availability of appropriate scalar sensors with sufficient time response and sensitivity (Wohlfahrt et al., 2012). Developments of high-precision, fast-response trace gas analysers, e.g. quantum cascade laser spectrometers (QCLAS), propelled the analysis of COS (Stimler et al., 2010a). Although these new devices are increasingly used for EC measurements (Asaf et al., 2013; Billesbach et al., 2014; Maseyk et al., 2014; Commane et al., 2015), a thorough characterisation of these instruments for flux measurements, an analysis of their limitations and the required corrections has not yet been conducted. So far the available studies have provided minimal methodological detail on the eddy covariance data processing, making it very hard to reproduce their work, which in turn is likely to hamper upcoming cross-site analyses.

In contrast to, for example, trace gas concentrations, for which national and international standards exist, to which calibration gases are referenced, no such standard exists for eddy covariance flux measurements of scalar or vector quantities, making it difficult if not impossible to assess their accuracy (Moncrieff et al., 1996). The best that can be done in such a situation is to compare these measurements against independent measurements, for example by assessing the energy balance closure (e.g. Foken, 2008) or by upscaling soil and leaf level $\mathrm{CO}_{2}$ exchange to the ecosystem scale (e.g. Moncrieff et al., 1996). Alternatively, confidence in flux estimates can be obtained by cross-comparisons of instruments (e.g. Peltola et al., 2014; Rannik et al., 2015) or postprocessing schemes (e.g. Mauder et al., 2008; Mammarella et al., 2016). If, as is the case for COS, no independent measurement approach exists, it is critical to at least explore the consequences of different processing steps that are known to cause systematic uncertainties in calculated fluxes (e.g. Sturm et al., 2012) in order to be able to quantify the likely magnitude of any systematic bias. At a recent COS workshop in Finland in September 2016 (Campbell et al., 2017), the lack of clear guidelines for making COS flux measurements and processing the resulting data was identified as a key gap for progress on understanding ecosystem-scale COS exchange.

The aim of this paper is thus to characterise the QCLAS for EC COS flux measurements and to determine the optimal EC processing procedures for its usage. To this end we use measurements obtained above a managed temperate mountain grassland in the Austrian Alps. We particularly focus on high- and low-pass filtering of the high-frequency data, quality assurance and quality control (QA/QC), characterise the random flux uncertainty and cross-compare our post-processing chain with independent $\mathrm{H}_{2} \mathrm{O}$ and $\mathrm{CO}_{2}$ flux measurements. Finally, the effects of these processing and filtering steps on obtained COS flux measurements are discussed.

\section{Materials and methods}

\subsection{Site description}

EC flux measurements were conducted during May-October 2015 at the FLUXNET site AT-Neu (FLUXNET, 2017), a managed temperate mountain grassland, located on the municipal territory of Neustift $\left(47^{\circ} 07^{\prime} \mathrm{N}, 11^{\circ} 19^{\prime} \mathrm{E}\right)$ in the Stubai Valley, Austria. The site is situated at an elevation of $970 \mathrm{~m}$ a.s.l. in the middle of the flat bottom of the Stubai Valley with a homogenous fetch that covers about 37 ha. Dominant daytime and night-time wind directions are northeasterly and south-westerly. The climate is humid continental, comprising alpine influences with an average annual temperature of $6.5^{\circ} \mathrm{C}$ and an average annual precipitation of $852 \mathrm{~mm}$. The snow-free months usually extend from midMarch to mid-November, leaving a vegetation period of 8 months. During 2015, four cutting events took place (on the 2 June, 7 July, 21 August and 1 October). For information about vegetation and soil conditions, we refer to Wohlfahrt et al. (2005b).

\subsection{Eddy covariance}

\subsubsection{Data acquisition}

The three wind components, as well as the sonic temperature, were measured by a 3-axis sonic anemometer (R3IA, Gill Instruments, Lymington, UK) at $2.5 \mathrm{~m}$ above ground level. Concentrations of $\mathrm{H}_{2} \mathrm{O}$ and $\mathrm{CO}_{2}$ were measured by two different devices: a closed-path infrared gas analyser (IRGA) (Li-7000, LICOR Biosciences, Lincoln, USA) and a QCLAS (Aerodyne Mini-QCL, Aerodyne Research Inc., Billerica, USA), additionally measuring COS at a wave number of ca. $2056 \mathrm{~cm}^{-1}$. Raw data were acquired on two separate PCs at $20 \mathrm{~Hz}$ (sonic anemometer and IRGA) and $10 \mathrm{~Hz}$ (QCLAS) using the EddyMeas (MPI Jena, Germany) and TDLWintel (Aerodyne, USA) software, respectively. The two PCs were synchronised in time using the NTP software (Meinberg, Germany). 
The QCLAS and associated hardware (thermocube and vacuum pump) were housed in a climate-controlled (ca. $30^{\circ} \mathrm{C}$ ) instrument hut situated near the flux tower. We insulated the QCLAS with an XPS (extruded polystyrene)insulating board with openings for necessary ports for additional temperature stabilisation and placed the vacuum pump on foam rubber to minimise influences by pump-induced vibrations on the laser optics. The QCLAS was operated at a pressure of 20 Torr using a built-in pressure controller and temperature of the optical bench and housing was controlled to $35^{\circ} \mathrm{C}$.

Sample air was drawn from the inlet through $15.7 \mathrm{~m}$ heated (ca. $40^{\circ} \mathrm{C}$ ) PFA Teflon tubing ( $4 \mathrm{~mm}$ inner diameter) that was installed at the beginning of the measurements in May 2015, through a filter (1-2 $\mu \mathrm{m}$, PTFE) to the QCLAS at a flow rate of ca. $6.5 \mathrm{~L} \mathrm{~min}^{-1}$. During the last five minutes of every halfhour, zero air ( $\mathrm{N}_{2}$ 5.0, Messer, Vomp, Austria) and span gas (pressurised air, Messer, Vomp, Austria; which was crosscompared to a NOAA standard with 567 ppt COS in air) was switched into the QCLAS in order to determine the stability of the instruments zero and span. The corresponding calibration coefficients were then applied on a half-hourly basis to derive calibrated concentrations.

In order to minimise flux loss, due to vertical and longitudinal sensor separation (Massman, 2000), we installed the intake tube for the QCLAS slightly below and laterally displaced from the sonic anemometer so that horizontal sensor separation was $0.1 \mathrm{~m}$ perpendicular to the main wind direction and the vertical sensor separation $0.1 \mathrm{~m}$.

\subsubsection{Data processing}

Subsetting of the $20 \mathrm{~Hz}$ sonic anemometer data to the $10 \mathrm{~Hz}$ resolution of the QCLAS data was done by using proprietary software (Hörtnagl et al., 2014) programmed in MATLAB 8.1.0 (R2013a, The MathWorks, Inc, USA). A 2-D coordinate rotation was performed according to Kaimal and Finnigan (1994). Using the post-processing software EdiRe (University of Edinburgh), eddy fluxes of $\mathrm{COS}, \mathrm{CO}_{2}$ and $\mathrm{H}_{2} \mathrm{O}$ were calculated as the covariance between the rotated vertical wind velocity and the scalar concentrations, using $25 \mathrm{~min}$ blocks of data. The QCLAS software applied the necessary spectroscopic corrections to account for the presence of water vapour and also converted concentrations to dry mole fractions (Neftel et al., 2010), avoiding the need for density corrections after Webb et al. (1980) during post-processing. The latter needed to be applied to the $\mathrm{CO}_{2}$ and $\mathrm{H}_{2} \mathrm{O}$ fluxes measured by the IRGA, assuming that temperature fluctuations were negligible due to sampling through a relatively long intake tube. The storage flux of COS was calculated as the time rate of change in COS molar density at the reference height and was confined to $\pm 2.7 \mathrm{pmol} \mathrm{m}^{-2} \mathrm{~s}^{-1}$ in $93 \%$ of all cases. In the following all fluxes are reported without the storage flux, except for when investigating the underestimation during periods of low turbulence (i.e. $u_{*}$-filtering).
Further details on the eddy covariance post-processing are presented in Sect. 3.

The determination of the total random flux uncertainty, which is due to the stochastic nature of turbulence and sensor noise, and the fraction of it that is due to sensor noise followed Langford et al. (2015), to which we refer for further details. Briefly, the approach infers the total random flux uncertainty based on Wienhold et al. (1995). In this approach the random flux uncertainty is calculated as the standard deviation of the cross-covariance at positive and negative lag times far away from the true lag, i.e. when the vertical wind speed and scalar concentrations may be supposed to be completely de-correlated. Following Langford et al. (2015) we used the RMSE instead of the standard deviation. Rannik et al. (2016) assessed the performance of the Wienhold et al. (1995) approach and found that it underestimated the true random flux uncertainty because the cross-covariances at neighbouring lags are not independent and suggest to calculate the standard deviation from cross-covariance estimates at intervals exceeding the integral timescale (e.g. $10 \mathrm{~s}$ ) over lag times of $\pm 100-300 \mathrm{~s}$, a suggestion which we followed. The standard deviation of the sensor noise was derived by linearly extrapolating the scalar auto-covariance function between 1 and 5 samples lag to zero lag (Langford et al., 2015). Based on that information a synthetic time series with a zero mean and 1 standard deviation derived from the previous step was generated and together with the true vertical wind speed time series used to calculate a cross-covariance function that would be obtained if there was just sensor noise. The corresponding random flux uncertainty was then derived the same way as the total random flux uncertainty (Langford et al., 2015).

\section{Results and Discussion}

\subsection{Lag-time determination}

Correcting for the travel time of the gas sample in the intake tube and the resulting lag time of the scalar time series with respect to the vertical wind velocity (lag time determination), is a key post-processing step for closed-path eddy covariance systems (McMillen, 1988). Additional time shifts may occur if the scalar and wind time series are acquired by different data acquisition systems due to drift of the respective clocks. While it would be desirable to avoid such time shifts caused by differing clocks of the data acquisition systems (Langford et al., 2015), we nevertheless chose this approach as preliminary tests showed that the TDLWintel software was unable to keep up the $10 \mathrm{~Hz}$ data acquisition rate if the sonic anemometer data were acquired on the same PC. To avoid PC clock drifts we used, based on earlier positive experience (Hörtnagl and Wohlfahrt, 2014; Pierce et al., 2015), a software (NTP, Meinberg, Germany) which kept the clocks synchronised throughout the measurement campaign. As shown 


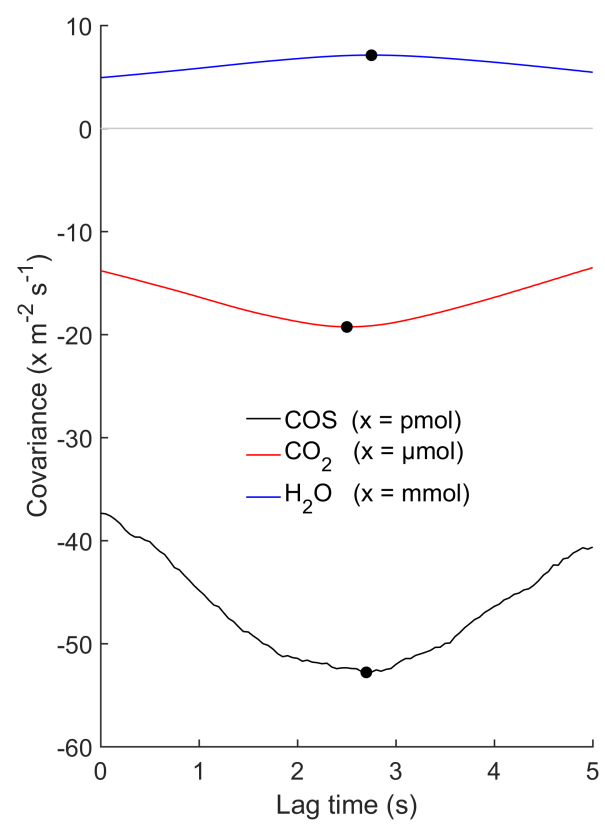

Figure 1. The covariance of vertical wind speed with the COS (black line), $\mathrm{CO}_{2}$ (red line) and $\mathrm{H}_{2} \mathrm{O}$ (blue line) molar density as a function of the (mostly) tube-induced time delay. Lag times in this example were $\mathrm{COS}=2.6 \mathrm{~s}, \mathrm{CO}_{2}=2.5 \mathrm{~s}, \mathrm{H}_{2} \mathrm{O}=2.85 \mathrm{~s}$. Data correspond to 5 July 2015 10:00-10:30 CET (Central European Time).

in Fig. 1, with this set-up the cross-correlation functions exhibited clear and, between scalars, consistent peaks (negative for $\mathrm{COS}$ and $\mathrm{CO}_{2}$ which exhibit net uptake, positive for $\mathrm{H}_{2} \mathrm{O}$ which is released to the atmosphere). The resulting lag times were slightly longer than nominal lag times calculated based on tube flow and dimensions (1.9 s), which has been found for other closed-path eddy covariance systems as well and likely reflects unaccounted volumes (e.g. QCLAS cell, filters), horizontal sensor separation and the scalar response time (Massman, 2000). This result illustrates the feasibility and reliability of acquiring scalar and sonic anemometer data on separate PCs, provided they are appropriately synchronised.

\subsection{High-pass filtering}

Laser spectroscopy-based eddy covariance flux measurements are well known to be sensitive to sensor drift, which may systematically bias flux estimates if not corrected for (Kroon et al., 2007; Mammarella et al., 2010). In order to quantify possible drift by the QCLAS we used Allan variance plots (Werle et al., 1993; Werle, 2010, 2011), generated by feeding the QCLAS with pressurised air under ambient conditions in the instrument shelter in the field. As shown in Fig. 2, the system was dominated by white noise up to an averaging time of ca. $10 \mathrm{~s}$ and started to drift in an approximately linear fashion after around $50 \mathrm{~s}$. Among the published COS eddy covariance flux studies (Asaf et al., 2013; Maseyk et al., 2014; Billesbach et al., 2014; Commane et al., 2015), this is the first time that QCLAS drift was characterised under field conditions. The Allan variance plot obtained by the manufacturer under laboratory conditions (Aerodyne Research, 2017) indicates white noise up to ca. $8 \mathrm{~s}$ integration time, which is quite comparable with Fig. 2. At longer integration times, however, the Allan variance plot by the manufacturer exhibits a much smaller increase with increasing averaging time. Most likely, this is the result of less stable thermal conditions in our instrument hut compared to laboratory conditions. This finding highlights the importance of optimising the experimental set-up (minimisation of temperature variations, insulation of QCLAS, etc.) for minimising sensor drift in the first place. In order to explore the effects of the drift on flux estimates, the following eddy covariance flux calculations were conducted for three high-pass filtering scenarios commonly used in the literature: (i) block averaging (BA), (ii) linear detrending (LD), and (iii) recursive filtering (RF) with a time constant of $50 \mathrm{~s}$ as determined from Fig. 2. In addition, we followed Wehr et al. (2017) and removed the measured instrument offset by linear interpolation between half-hourly background measurements, termed linear background correction (LBC). The latter approach assumes the linear interpolation of half-hourly background measurements (median absolute COS change equal to $20 \mathrm{ppt}$ ) to successfully represent any sensor drift, while LD and RF may remove real flux in case of true trends in the ambient concentration time series.

\subsection{High-frequency correction}

Cospectral analyses, shown for unstable conditions and horizontal wind speeds of $1.00-1.25 \mathrm{~m} \mathrm{~s}^{-1}$ in Fig. 3, demonstrate the expected high-frequency correction (low-pass filtering) of COS at normalised frequencies $>0.5$, (natural frequency normalised with the measurement height above the zero-plane displacement height and mean horizontal wind speed) caused by the combined effects of tube attenuation, limited sensor time response, path averaging and sensor separation (e.g. Moncrieff et al., 1997; Massman, 2000). At normalised frequencies $>1.5$, the low-pass filtering effects described above apparently weakened, which coincides with the normalised frequency at which COS power spectra became less dependent on frequency, which suggests an increasing influence of white noise (Eugster et al., 2007). The same behaviour was found for $\mathrm{CO}_{2}$ and $\mathrm{H}_{2} \mathrm{O}$, However for these two the effects of low-pass filtering appeared at higher and lower frequencies, respectively, while the onset of noise was confined to the highest frequencies. Similar findings, i.e. noise appearing in the power spectra at natural frequencies $>0.19 \mathrm{~Hz}$, were reported by Eugster et al. (2007) using a QCL for $\mathrm{N}_{2} \mathrm{O}$ flux measurements above a mixed forest in Switzerland. Figure 3 also shows the ratio of the $\mathrm{COS} / \mathrm{CO}_{2} / \mathrm{H}_{2} \mathrm{O}$ to sensible heat cospectra. Recognising that sensible heat cospectra are only marginally af- 

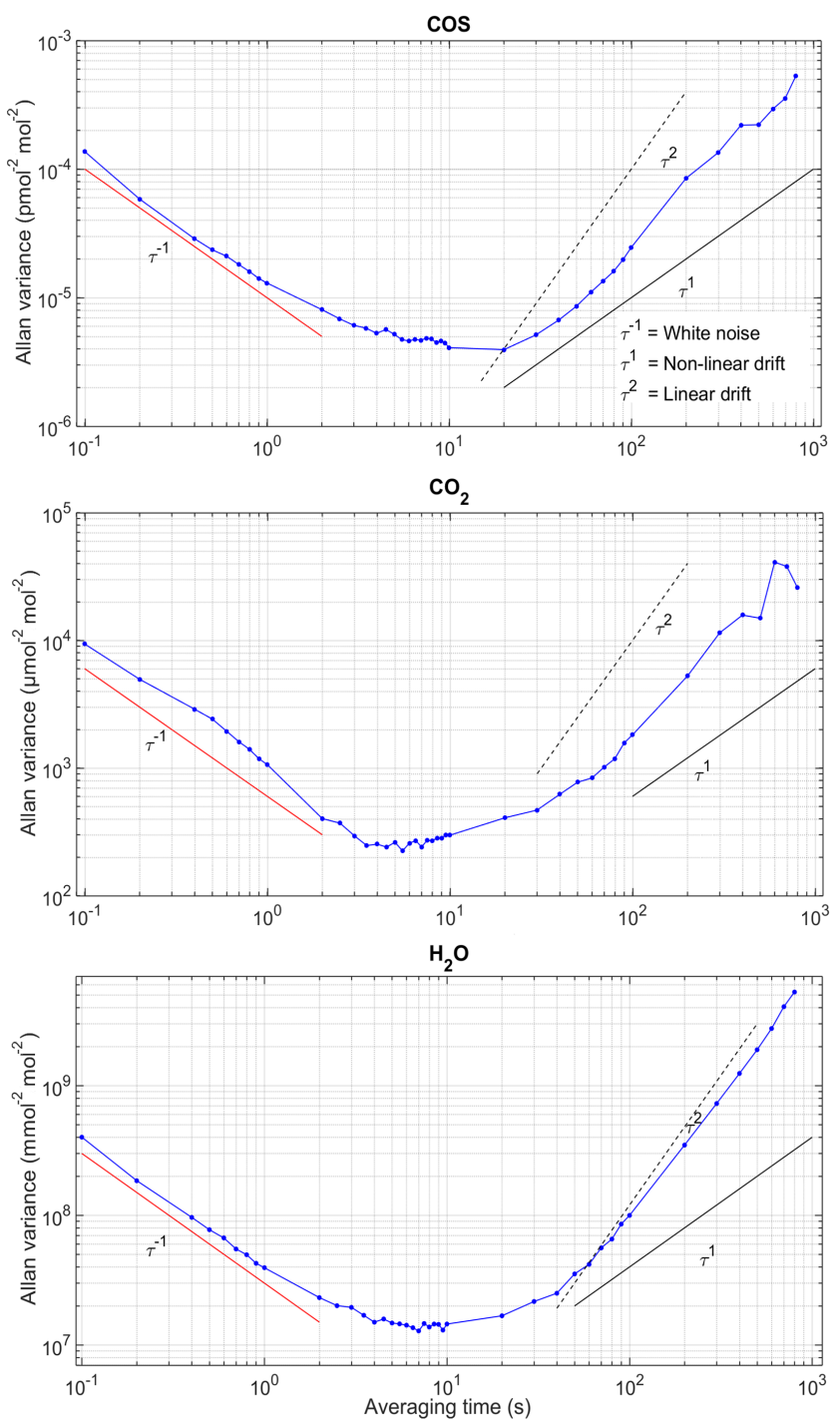

Figure 2. Plots of the Allan variance (blue symbols and lines) as a function of the averaging time $(\tau)$ as described in Werle (2010). The time series was obtained under ambient conditions in the instrument hut in the field by providing pressurised air from a cylinder to the QCLAS. The red line indicates the expected decline of the variance with increasing averaging time in case of white noise; the black dashed and solid lines are the expected increase in variance due to non-linear and linear drift, respectively.

fected by low-pass filtering, these ratios represent experimentally derived transfer functions for low-pass filtering of COS, $\mathrm{CO}_{2}$ and $\mathrm{H}_{2} \mathrm{O}$. Following Aubinet et al. (2001), each of these transfer functions was fit to a one-parameter sigma function by optimising the half-point frequency (indicated by vertical dotted lines in the lowermost panels of Fig. 3). By integrating the ratio of the sensible heat cospectrum to the sensible heat cospectrum convoluted with the experimental transfer function, an experimental high-pass filtering correction factor (Aubinet et al., 2001) could be obtained for each species, three stability conditions $(z / L<-0.25$; $-0.25<z / L<0.25, z / L>0.25)$ and eight wind speed classes $\left(0.25 \mathrm{~m} \mathrm{~s}^{-1}\right.$ bin size in $0-2 \mathrm{~m} \mathrm{~s}^{-1}$ range). Consistent with Aubinet et al. (2001), the experimentally derived low-pass filtering correction factors scaled linearly with the horizontal wind speed (Fig. 4). Even though low-pass filtering coefficients are expected to be larger for stable compared to unstable/neutral conditions, no such effect was observed. This reflects the findings of Wohlfahrt et al. (2005a), who showed that sensible heat cospectra at this site change much less from unstable/neutral to stable conditions compared to the classical Kaimal cospectra (Kaimal and Finnigan, 1994). Thus a single linear relationship forced through unity was fitted to all experimental low-pass filtering correction factors independent of stability (Fig. 4). These linear relationships explained $>71 \%$ of the variability, with slopes of $0.19 \mathrm{~s} \mathrm{~m}^{-1}$ (COS), $0.18 \mathrm{~s} \mathrm{~m}^{-1}\left(\mathrm{CO}_{2}\right)$ and $0.31 \mathrm{~s} \mathrm{~m}^{-1}\left(\mathrm{H}_{2} \mathrm{O}\right)$. For comparison, using a closed-path IRGA and similar tubing dimension and flow rate, but half the tube length, Aubinet et al. (2001) obtained slopes of 0.044 and $0.063 \mathrm{~s} \mathrm{~m}^{-1}$ for $\mathrm{CO}_{2}$ and $\mathrm{H}_{2} \mathrm{O}$, respectively. The close correspondence between the slopes for $\mathrm{COS}$ and $\mathrm{CO}_{2}$ lends support to other studies (e.g. Wehr et al., 2017), which based low-pass filtering corrections of $\mathrm{COS}$ on those determined for $\mathrm{CO}_{2}$. The larger slope (and thus larger low-pass filtering) for $\mathrm{H}_{2} \mathrm{O}$ compared to $\mathrm{COS}$ and $\mathrm{CO}_{2}$ is likely due to interactions of water with the tubing (Ibrom et al., 2007), even though it was heated in this study. A more detailed correction for $\mathrm{H}_{2} \mathrm{O}$ could be obtained by analysing the dependency of the correction factor on relative humidity, as in Mammarella et al. (2009). The linear relationships with wind speed were then used to correct for low-pass filtering. The overall frequency response corrections included these low-pass filtering corrections, as well as high-pass filtering due to block averaging and linear detrending or recursive filtering (where applicable).

\subsection{Quality control}

For quality control, first, biologically or physically implausible flux values were discarded by percentile filtering, leaving $81 \%$ of the COS (5th-95th percentile) and $89 \%$ of both the $\mathrm{CO}_{2}$ and $\mathrm{H}_{2} \mathrm{O}$ (1st-99th percentile) flux data. See Table 1 for the corresponding flux limits.

Stationarity, i.e. that the scalar and vertical wind velocity time series and their covariance do not vary over time, is a basic requirement of the eddy covariance method. The stationarity test by Foken and Wichura (1996) assesses how much the covariance deviates (in \%) from perfect stationarity by comparing the mean covariance calculated from shorter sub-periods (six $4 \mathrm{~min}$ periods in our case) to the $25 \mathrm{~min}$ average. Following Foken and Wichura (1996) the results were binned into five classes $(0-15,15-30,30-60,60-100$ and $>100 \%$ deviation). As shown in Fig. 5, the application of high-pass filtering (LD and RF) compared to block averaging significantly increased the fraction of acceptable data $\left(\chi^{2}-\right.$ 

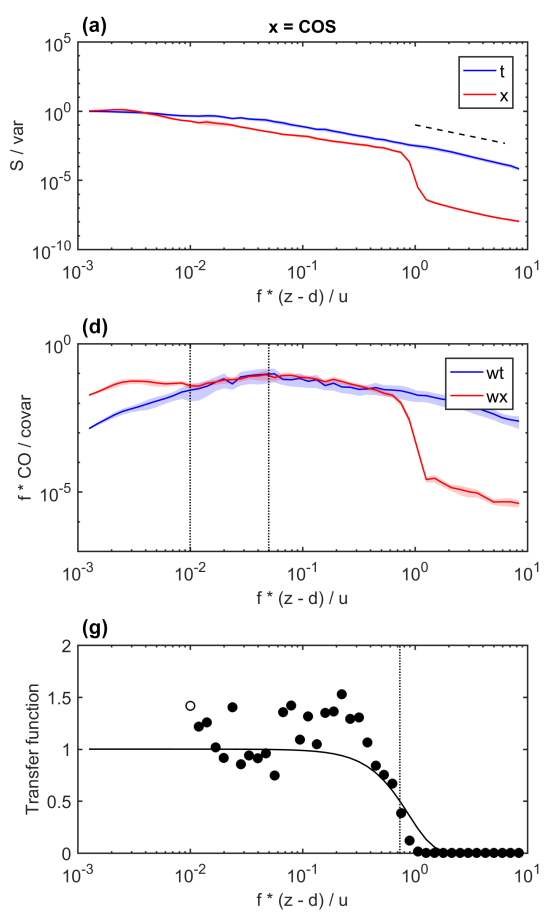
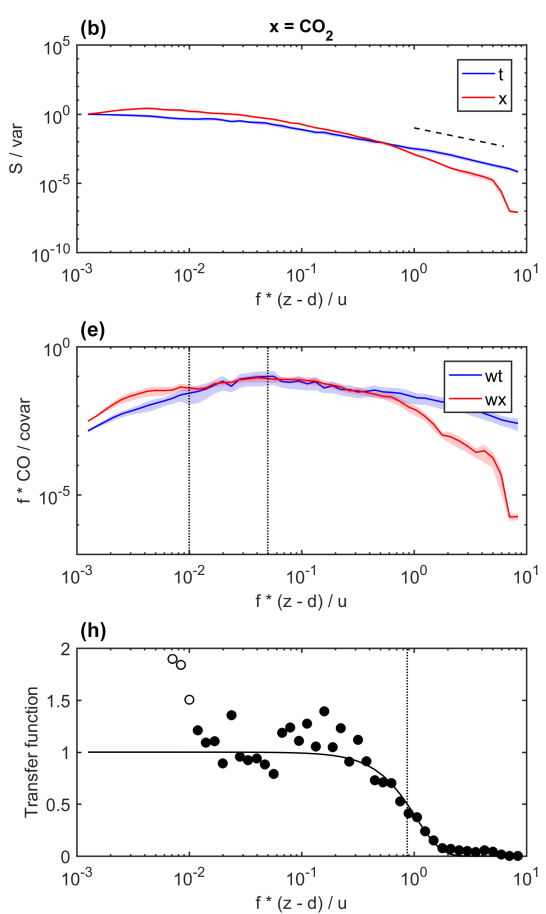
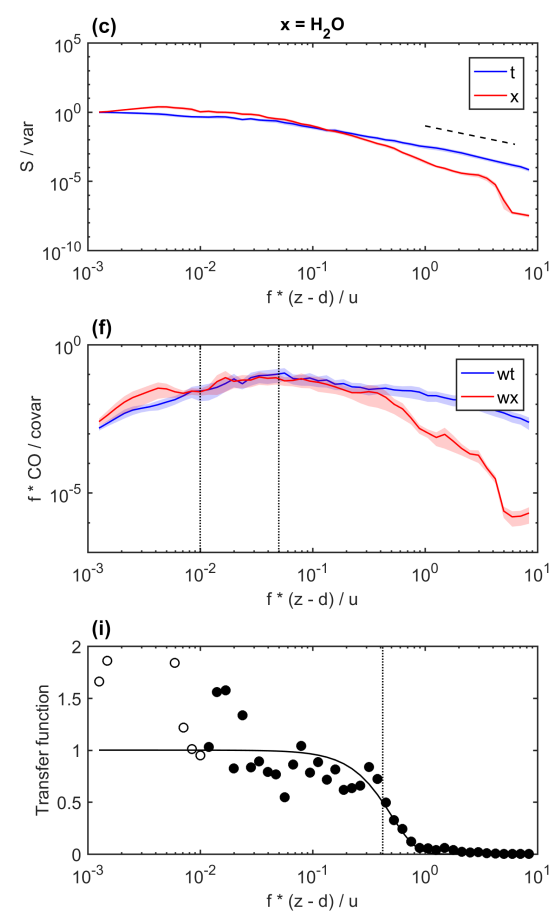

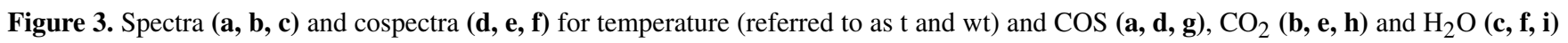
(referred to as $x$ and $w x$, with $x$ representing the three scalars). Spectra (S) and cospectra (CO) were normalised by their variance (var) and covariance (covar), respectively. The natural frequency $(f)$ was normalised by the measurement height above the zero-plane displacement height $(z-\mathbf{d})$ and the mean horizontal wind speed $(u)$. Solid lines and shaded areas refer to the average and 1 standard error. Data were filtered for unstable conditions $(z / L<-0.25)$ and wind speeds between 1.00 and $1.25 \mathrm{~m} \mathrm{~s}^{-1}$. The dashed line in the upper panel indicates the expected $-5 / 3$ decay in the inertial subrange. Vertical dotted lines in the middle panel encompass the frequencies between which cospectra were normalised to each other. The lower panels show experimental transfer functions as the ratio of the normalised $\mathrm{COS} \mathrm{CO}_{2}$ and $\mathrm{H}_{2} \mathrm{O}$ to temperature cospectra. Vertical dotted lines in the lower panels indicate the half-point frequency. Only data indicated by closed symbols in the lower panels were used to estimate the half-point frequency.

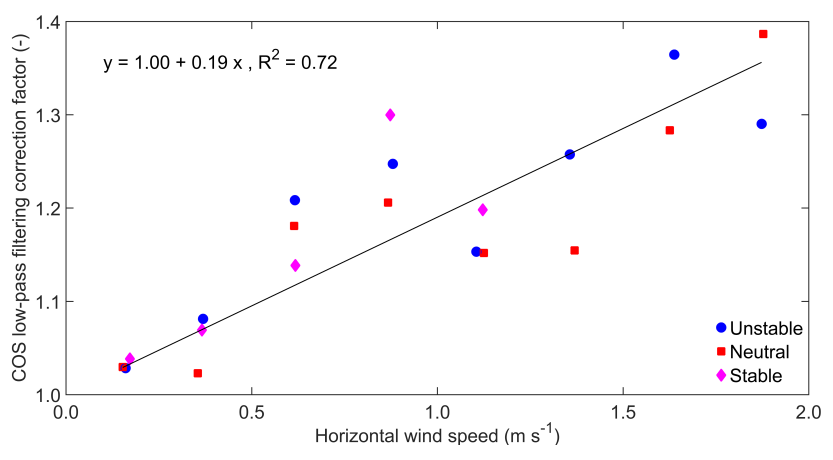

Figure 4. Wind speed dependence of experimentally derived low-pass filtering correction factors for COS. Symbols refer to different stability conditions (unstable: $z / L<-0.25$; neutral: $-0.25 \leq z / L \leq 0.25$; stable: $z / L>0.25$ ), the solid black line to a linear regression (coefficients and coefficient of determination are indicated in the upper-left corner).

test, $p=0.000$ for all cases) in the lowest category from $19 \%$ BA to $41 \% \mathrm{RF}$ for COS, $33 \% \mathrm{BA}$ to $51 \% \mathrm{RF}$ for $\mathrm{CO}_{2}$ and $28 \% \mathrm{BA}$ to $41 \% \mathrm{RF}$ for $\mathrm{H}_{2} \mathrm{O}$, and decreased in all other cat- egories. The most prominent decline was observed in the 60$100 \%$ class with $19 \% \mathrm{BA}$ to $9 \% \mathrm{RF}$ for COS, $15 \% \mathrm{BA}$ to $12 \% \mathrm{RF}$ for $\mathrm{CO}_{2}$ and $21 \% \mathrm{BA}$ to $13 \% \mathrm{RF}$ for $\mathrm{H}_{2} \mathrm{O}$. Allowing a maximum deviation of $100 \%$, between $67 \%$ (BA) to $79 \%(\mathrm{RF})(\mathrm{COS})$ and $75 \%(\mathrm{BA})$ to $82 \%(\mathrm{RF})\left(\mathrm{CO}_{2}\right)$ passed the stationarity test (Table 1). The linear background correction (LBC), available only for COS, performed similarly to BA (Table 1).

Different authors have shown that during periods of low turbulence and stable stratification, typical night-time conditions, eddy flux measurements can systematically underestimate ecosystem respiration (Goulden et al., 1996; Aubinet et al., 2000; Papale et al., 2006; Gu et al., 2005; Wohlfahrt et al., 2005a). To assess any underestimation of night-time $\left(\mathrm{PAR}<5 \mu \mathrm{mol} \mathrm{m}{ }^{-2} \mathrm{~s}^{-1}\right.$ ) fluxes we plotted $\mathrm{CO}_{2}$ and $\mathrm{COS}$ fluxes as a function of the friction velocity $\left(u_{*}\right)$ by using a change point detection algorithm (Barr et al., 2013). As shown in Fig. 6, the absolute magnitude of both COS and $\mathrm{CO}_{2}$ fluxes were positively related to friction velocity in the lower range of friction velocities, which is presently understood to indicate insufficient turbulent mixing (Massman and Lee, 2002). Only when fluxes become indepen- 
Table 1. List of flags, their limiting values and the percentage of data left after application, for each gas. The first two criteria pertain to all gases and processing scenarios. Block averaging - BA, linear detrending - LD, recursive filtering - RF linear background correction - LBC).

\begin{tabular}{|c|c|c|c|c|c|c|c|c|}
\hline Exclusion criteria & \multicolumn{4}{|c|}{ Limiting value } & \multicolumn{4}{|c|}{ Data left $(\%)$} \\
\hline Integral turbulence test (\%) & \multicolumn{4}{|c|}{$\leq 100$} & \multicolumn{4}{|c|}{99} \\
\hline Footprint (\%) & \multicolumn{4}{|c|}{$\geq 80$} & \multicolumn{4}{|c|}{90} \\
\hline $\cos$ & BA & LD & RF & LBC & BA & LD & RF & LBC \\
\hline Flux range $\left(\mathrm{pmol} \mathrm{m}^{-2} \mathrm{~s}^{-1}\right)$ & -91 to 29 & -79 to 19 & -65 to 8 & -100 to 49 & \multicolumn{4}{|c|}{81} \\
\hline$u_{*}\left(\mathrm{~m} \mathrm{~s}^{-1}\right)$ & 0.08 & 0.10 & 0.12 & 0.09 & 72 & 61 & 53 & 68 \\
\hline Stationarity $(\%)$ & \multicolumn{4}{|c|}{$\leq 100$} & 67 & 74 & 79 & 68 \\
\hline All exclusion criteria & \multicolumn{4}{|c|}{-} & 50 & 44 & 39 & 45 \\
\hline $\mathrm{CO}_{2}$ & BA & LD & RF & LBC & & & & \\
\hline Flux range $\left(\mu \mathrm{mol} \mathrm{m}{ }^{-2} \mathrm{~s}^{-1}\right)$ & -42 to 97 & -35 to 78 & -28 to 42 & - & & 89 & & - \\
\hline$u_{*}\left(\mathrm{~m} \mathrm{~s}^{-1}\right)$ & 0.12 & 0.12 & 0.14 & - & 55 & 54 & 45 & - \\
\hline Stationarity $(\%)$ & & $\leq 100$ & & - & 75 & 78 & 82 & - \\
\hline All exclusion criteria & & & & & 46 & 46 & 40 & - \\
\hline $\mathrm{H}_{2} \mathrm{O}$ & BA & LD & RF & LBC & & & & \\
\hline Flux range $\left(\mathrm{mmol} \mathrm{m}^{-2} \mathrm{~s}^{-1}\right)$ & -2 to 10 & -0.7 to 10 & -0.3 to 10 & - & & 89 & & - \\
\hline$u_{*}\left(\mathrm{~m} \mathrm{~s}^{-1}\right)$ & & & & & & - & & - \\
\hline Stationarity $(\%)$ & & $\leq 100$ & & - & 70 & 74 & 76 & - \\
\hline All exclusion criteria & & & & & 68 & 71 & 73 & - \\
\hline
\end{tabular}
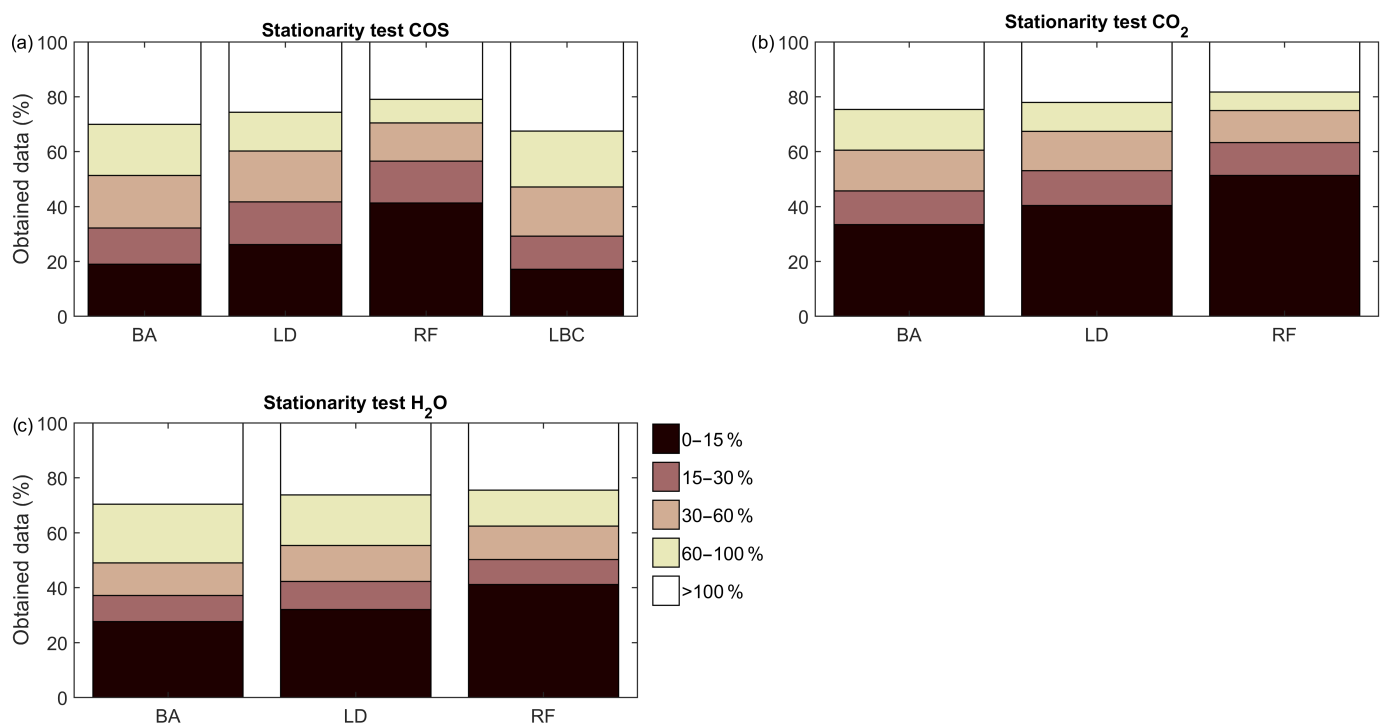

Figure 5. Stationarity test after Foken and Wichura (1996) for $\mathrm{COS}(\mathbf{a}), \mathrm{CO}_{2}$ (b) and $\mathrm{H}_{2} \mathrm{O}$ (c) fluxes calculated for different high-pass filtering scenarios: block averaging (BA), linear detrending (LD), recursive filtering (RF) and linear background correction (LBC; COS only). The colour coding refers to percentage deviations from perfect stationarity (Foken and Wichura, 1996).

dent of friction velocity, i.e. for friction velocities higher than 0.12 to $0.14 \mathrm{~m} \mathrm{~s}^{-1}\left(\mathrm{CO}_{2}\right)$ and 0.09 to $0.12 \mathrm{~m} \mathrm{~s}^{-1}$ (COS), turbulent mixing is deemed sufficient to not result in a systematic underestimation of night-time fluxes. Using an infrared gas analyser for $\mathrm{CO}_{2}$ flux measurements, Wohlfahrt et al. (2005a) found $u_{*}$ thresholds between 0.1 and $0.15 \mathrm{~m} \mathrm{~s}^{-1}$ for the same study site. Adopting the $u_{*}$ threshold deter- mined for $\mathrm{CO}_{2}$ for $\mathrm{COS}$, as done for example by Commane et al. (2015), thus appears not to result in larger differences. Using these thresholds to filter data, between 28-47 and 45$55 \%$ of the $\mathrm{COS}$ and $\mathrm{CO}_{2}$ fluxes respectively were excluded, with RF removing the largest and BA the smallest fraction of data (Table 1). 

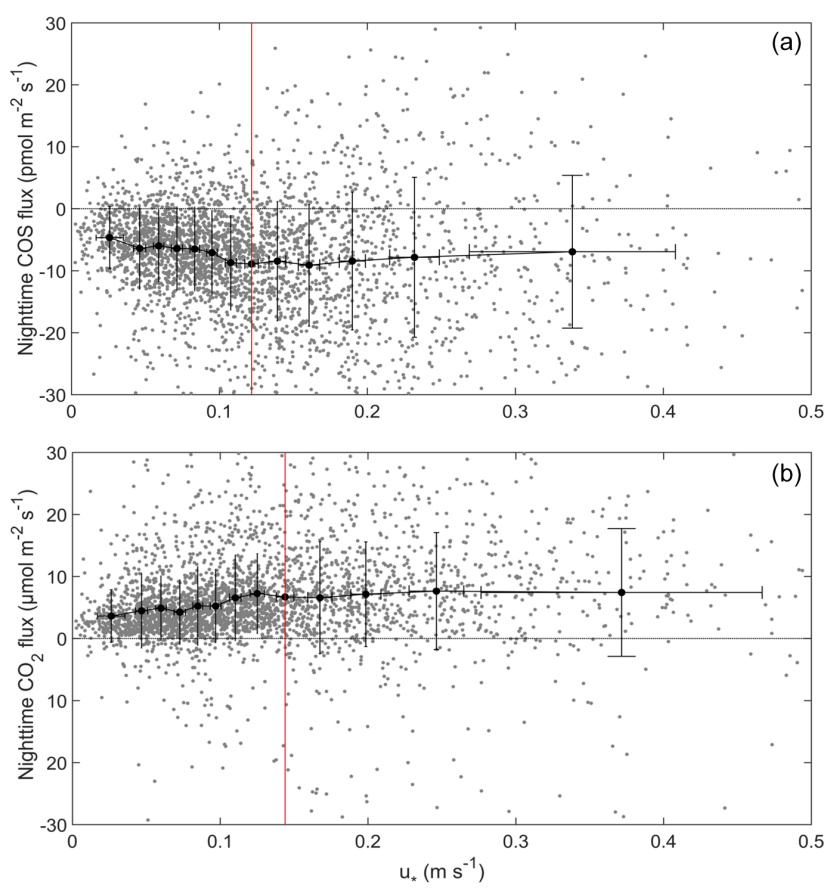

Figure 6. Nocturnal $\mathrm{COS}$ (a) and $\mathrm{CO}_{2}$ (b) fluxes (inclusive of the storage term) as a function of friction velocity $\left(u_{*}\right)$. The flux data, calculated with a recursive filter (RF) using a time constant of $50 \mathrm{~s}$, were divided into 13 bins. The $u_{*}$ threshold (vertical red line) was determined on the basis of the change point detection algorithm by Barr et al. (2013).

The following two quality criteria were applied independently from the scalar and high-pass filtering method.

The integral turbulence test (Foken and Wichura, 1996) is able to identify deviations of mechanical turbulence from expected Monin-Obukhov similarity theory (Monin and Obukhov, 1954), caused for example by flow over complex terrain or flow distortion by measurement infrastructure. Allowing a maximum deviation of $100 \%, 1 \%$ of the data were excluded by the integral turbulence test with a larger fraction, mostly during night-time, since it was excluded from the sector where the instrument hut is located.

In order to remove unwanted flux contributions by other ecosystem types (forest or settlements) beyond the study site, we used the footprint model by Hsieh et al. (2000) and required $80 \%$ of the flux to originate from within the grassland area, which removed $10 \%$ of all data.

After applying all quality criteria to the data set, between $39 \%$ (RF-COS) and $73 \%\left(\right.$ RF- $\left.\mathrm{H}_{2} \mathrm{O}\right)$ of the data were retained.

\subsection{Random flux uncertainty}

As shown in Fig. 7, the total random flux uncertainty (due to the stochastic nature of turbulence and sensor noise) was smallest for RF, followed by LD, and largest with BA (and
LBC); i.e. the two high-pass filtering approaches, in particular RF, reduced the random flux uncertainty. Random uncertainties vanish with increasing sample size (Moncrieff et al., 1996), which increases the likelihood of being able to detect relationships between fluxes estimates (e.g. the ecosystem relative uptake rate; Asaf et al., 2013) and between fluxes and environmental conditions. The random flux uncertainty that was due to sensor noise was at least 1 order of magnitude smaller than the total random flux uncertainty and barely differed between the high-pass filtering scenarios (dashed lines in Fig. 7). As a consequence, sensor noise made a relatively larger contribution to the total random flux uncertainty of RF and $\mathrm{LD}$ as opposed to BA (and LBC).

\subsection{Cross-comparison with IRGA $\mathrm{CO}_{2}$ and $\mathrm{H}_{2} \mathrm{O}$ fluxes}

An independent cross-comparison of the entire postprocessing chain was conducted by comparison with $\mathrm{CO}_{2}$ and $\mathrm{H}_{2} \mathrm{O}$ eddy covariance fluxes routinely measured with the closed-path IRGA at the study site. The results are shown in Fig. 8. Both data sets were filtered for flux range, stationarity, footprint and integral turbulence characteristics as described above. IRGA fluxes were calculated based on block averaging only, due to negligible sensor drift. For $\mathrm{CO}_{2}$, the results confirm that the QCLAS is capable of accurately measuring the eddy fluxes as also found by Billesbach et al. (2014), who compared $\mathrm{CO}_{2}$ fluxes measured with the same model of QCLAS and an open-path IRGA. QCLAS-derived $\mathrm{H}_{2} \mathrm{O}$ fluxes were ca. $15 \%$ higher than those measured with the IRGA, which may be indicative of problems with the closedpath IRGA-based $\mathrm{H}_{2} \mathrm{O}$ flux measurements (Ibrom et al., 2007) as evident in the lack of energy balance closure (the sum of the latent and sensible heat exchange falling short of the available energy by ca. $25 \%$; Haslwanter et al., 2009). Possibly, the correspondence could be improved by accounting for variability in relative air humidity in the low-pass filtering corrections, as suggested by Ibrom et al. (2007) or Mammarella et al. (2009). The statistics $\left(R^{2}, \mathrm{MAE}\right)$ showed only minor differences between the three processing procedures, indicating that our cross-comparison provides no definite outcome in favour of choosing a specific high-pass filter. We however emphasise that this cross-comparison cannot validate the COS fluxes, due to the differences in line strength and noise properties compared to $\mathrm{CO}_{2}$ and $\mathrm{H}_{2} \mathrm{O}$.

\subsection{COS exchange}

Finally, we investigated how the four processing procedures (BA, LD, RF, LBC) affect the COS flux estimates. As shown in Fig. 9a, the mean diurnal cycles of the COS exchange were overall quite similar between the processing options, but RF and, to a lesser degree, $\mathrm{LD}$ tended to yield less negative fluxes than BA and LBC. For $\mathrm{CO}_{2}$ fluxes (Fig. 9b), differences between the three processing options $(\mathrm{BA}, \mathrm{LD}, \mathrm{RF})$ were basi- 

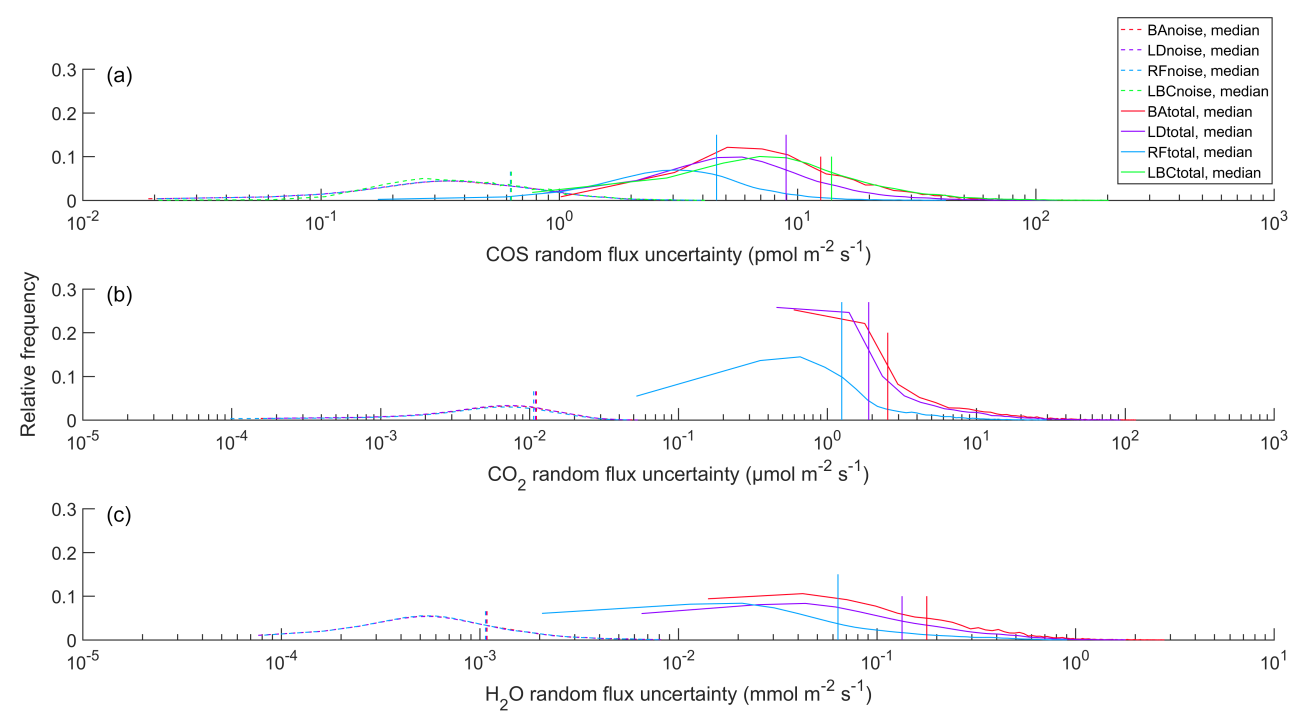

Figure 7. Frequency distribution of calculated total random uncertainties (solid lines) and instrument noise (dashed lines) for COS (a), $\mathrm{CO}_{2}$ (b) and $\mathrm{H}_{2} \mathrm{O}$ (c) and different high-pass filtering scenarios (block averaging - BA, linear detrending - LD, recursive filtering - RF, LBC - linear background correction). The vertical lines indicate the respective median values.
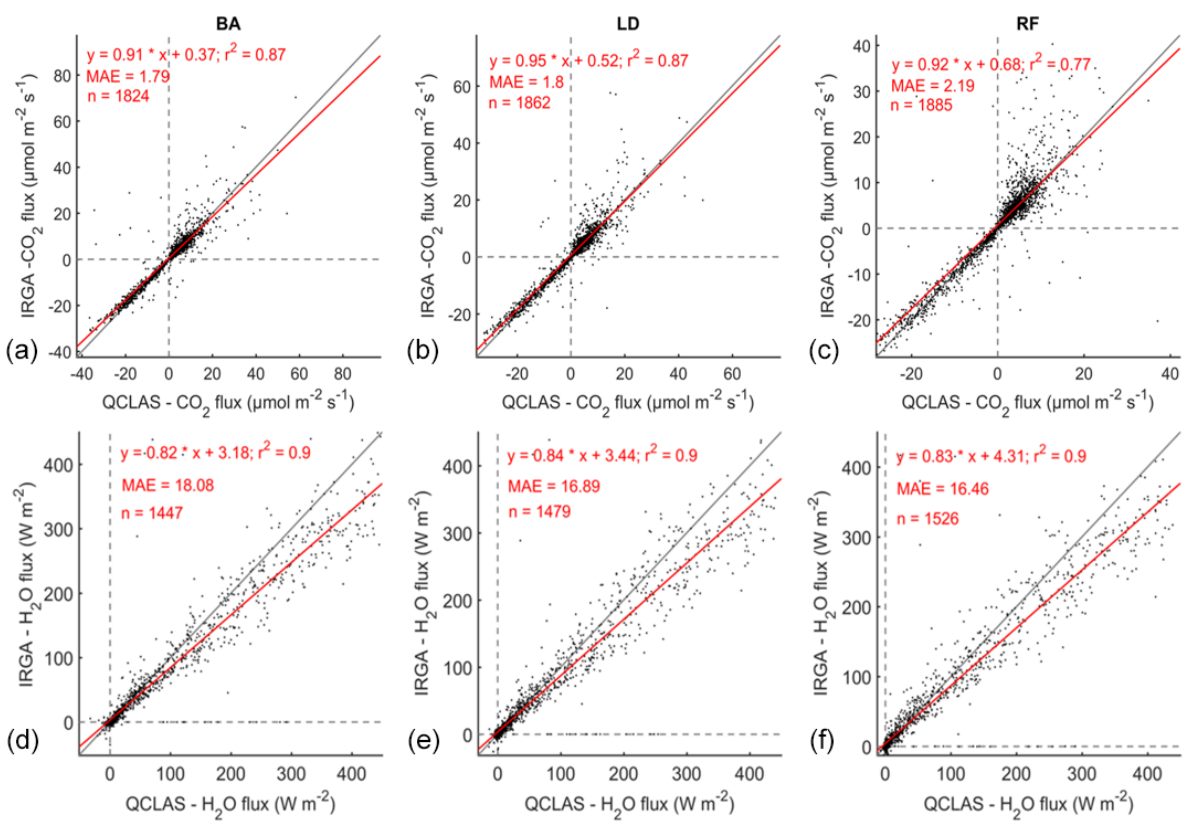

Figure 8. Correlation between IRGA and QCLAS $\mathrm{CO}_{2}(\mathbf{a}, \mathbf{b}, \mathbf{c})$ and $\mathrm{H}_{2} \mathrm{O}(\mathbf{d}, \mathbf{e}, \mathbf{f})$ fluxes using block averaging $(\mathrm{BA}, \mathbf{a}, \mathbf{d})$, linear detrending $(\mathrm{LD}, \mathbf{b}, \mathbf{e})$ and a recursive filter with a $50 \mathrm{~s}$ time constant $(\mathrm{RF}, \mathbf{c}, \mathbf{f})$. The solid grey line indicates the $1: 1$ line and the solid red line is the geometric mean regression fit. The regression coefficients, the coefficient of determination $\left(r^{2}\right)$, the mean absolute error (MAE) and the number of samples $(n)$ are indicated in each panel.

cally absent during daytime, while during night-time RF and LD yielded clearly lower fluxes.

In order to link the $\mathrm{COS}$ to the $\mathrm{CO}_{2}$ exchange (e.g. gross primary productivity), a primary motivation for conducting ecosystem-scale COS exchange measurements (Wohlfahrt et al., 2012), the concept of the leaf relative uptake rate (LRU; Sandoval-Soto et al., 2005) has been instrumental (e.g. Asaf et al., 2013). The LRU represents the ratio of the $\mathrm{COS}$ to $\mathrm{CO}_{2}$ deposition velocity and has been suggested to converge to a value of ca. 1.7 under conditions of high radiation (Berkelhammer et al., 2014). An emerging pattern, both at the leaf (e.g. Stimler et al., 2010b, 2011) and ecosystem scale (e.g. Maseyk et al., 2014; Commane et al., 2015; Wehr et al., 2017), is that the LRU and ecosystem relative uptake rate 

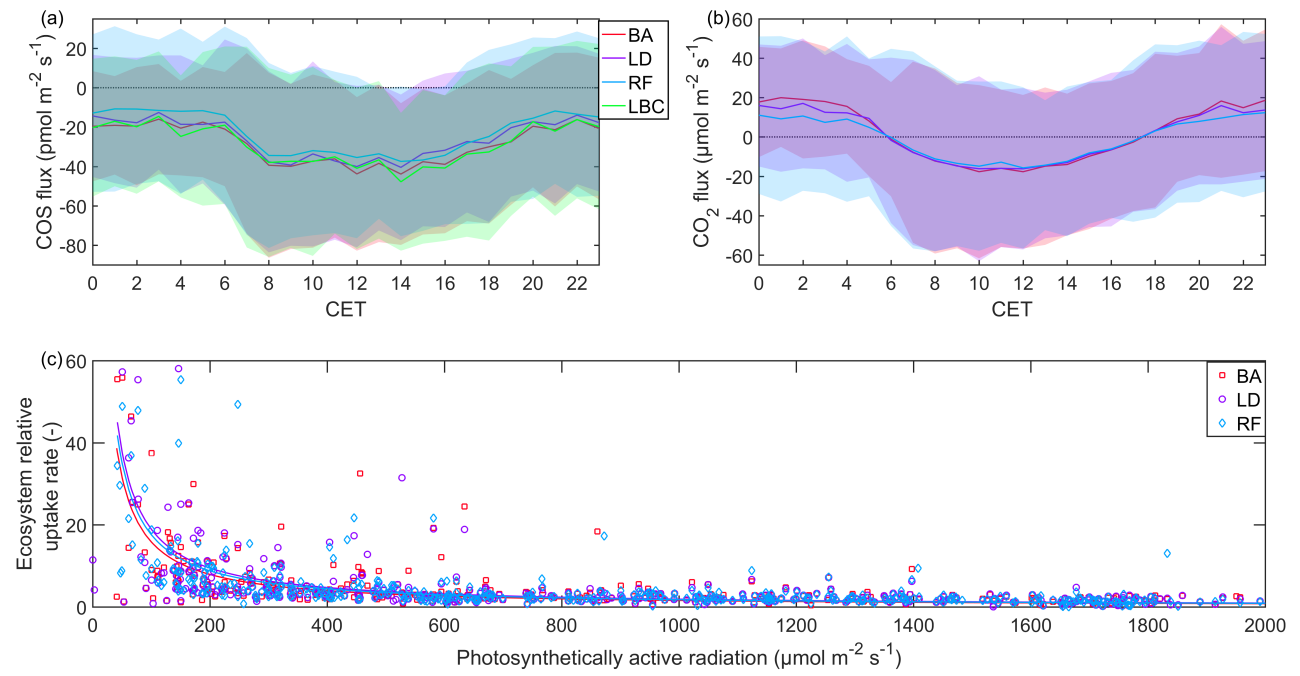

Figure 9. Mean diurnal variation of the $\mathrm{COS}(\mathbf{a})$ and $\mathrm{CO}_{2}$ (b) exchange and light dependency of the ecosystem relative uptake rate (c) calculated based on different high-pass filtering scenarios (block averaging - BA, linear detrending - LD, recursive filtering - RF, linear background correction - LBC (COS only)). Data were filtered as described in the text. In addition, data shown in panel c were filtered for negative $\mathrm{COS}$ and $\mathrm{CO}_{2}$ fluxes and a leaf area index $\geq 5 \mathrm{~m}^{2} \mathrm{~m}^{-2}$. CET stands for Central European Time.

(ERU; the concept of LRU extended to the ecosystem-scale) deviate (increase) from a constant value at low light intensities. This increase is due to the progressive limitation of photosynthesis at low light, which does not affect COS uptake, as the carbonic anhydrase, the enzyme responsible for the hydrolysis of COS, is thought to be light independent (Wehr et al., 2017). As shown in Figure 9c, the various processing options reproduced the increase in ERU with decreasing incident light, with few differences between BA, LD and RF, suggesting that the underestimation of $\mathrm{COS}$ and $\mathrm{CO}_{2}$ fluxes with RF and LD (Fig. 9a and b) tends to cancel out in the ERU.

\section{Conclusion}

Even though the number of published eddy covariance COS flux measurements has increased significantly during the past few years (Asaf et al., 2013; Billesbach et al., 2014; Maseyk et al., 2014; Commane et al., 2015; Wehr et al., 2017), this is the first study to systematically examine the use of QCLAS instruments for making defensible COS flux measurements, the necessary processing steps and QA/QC procedures, and to characterise the random flux uncertainty.

We found flux measurements to be affected by sensor drift (e.g. Mammarella et al., 2010), which was accounted for using two common high-pass filtering methods, linear detrending (LD) and recursive filtering (RF). We compared these results with flux calculations based on simple block averaging (BA) and by linear removal of regular background measurements (LBC). LD and RF are based on the measured time series only and their application thus risks remov- ing true changes in ambient concentrations and corresponding flux contributions (Mammarella et al., 2010). LBC, in contrast, accounts for changes in the QCLAS background on the basis of half-hourly background measurements and attempts to remove these changes by linear interpolation (Wehr et al., 2017). Even though the Allan variance analysis (Fig. 2) showed drift not to be strictly linear, LBC may thus be considered conceptually superior for correcting for sensor drift. Yet, in this study LBC yielded fluxes that were very close to those calculated with BA (Fig. 9), suggesting that the sensor drift over half-hourly periods (median of absolute COS changes: $20 \mathrm{ppt}$ ) had a small effect on inferred fluxes. LD and RF, as expected, yielded fluxes that were lower compared to BA (and LBC). However, when COS and $\mathrm{CO}_{2}$ fluxes were combined in the ERU, differences between the high-pass filtering scenarios largely cancelled out. Minor differences between different high-pass filtering methods were also obtained in the cross-comparison with independent IRGA-based $\mathrm{CO}_{2}$ and $\mathrm{H}_{2} \mathrm{O}$ fluxes (Fig. 8). By using the high-pass filtering operations, LD and RF expectedly increased the fraction of data retained in the stationarity test, but at the same time LD and RF were associated with higher $u_{*}$ thresholds, which caused more night-time data to be excluded, resulting in overall similar fractions of data retained after QC (Table 1). While high-pass filtering, operating at lower frequencies, did not affect the random flux uncertainty due to sensor noise, RF and LD reduced the total random flux uncertainty (due to the stochastic nature of turbulence and sensor noise) compared to BA (and LBC) by the same mechanism that increases stationarity and reduces the flux.

This is the first study to directly address low-pass filtering and $u_{*}$-filtering for COS eddy covariance flux measurements 
and shows that previous ad hoc approaches assuming similarity to $\mathrm{CO}_{2}$ appear not to cause systematic bias. Overall, our study thus suggests that previous studies, even though they use different post-processing approaches, should be reasonably comparable, in particular with regard to ERU estimates, paving the way for corresponding first cross-site syntheses.

Data availability. The data underlying this article partially form the basis of the $\mathrm{PhD}$ project of Felix M. Spielmann, who is preparing at least one manuscript based on these data. Once these manuscripts have been published, the data will be available upon request to Georg Wohlfahrt (georg.wohlfahrt@uibk.ac.at).

Competing interests. The authors declare that they have no conflict of interest.

Acknowledgements. This work was funded by the Austrian National Science Fund (FWF) under contract P27176-B16. We thank the family Hofer (Neustift, Austria) for kindly granting us access to the study site.

Edited by: Thomas F. Hanisco

Reviewed by: two anonymous referees

\section{References}

Aerodyne Research: http://www.aerodyne.com/products/ carbonyl-sulfide-monitors, last access: 17 September 2017.

Asaf, D., Rotenberg, E., Tatarinov, F., Dicken, U., Montzka, S. A., and Yakir, D.: Ecosystem photosynthesis inferred from measurements of carbonyl sulphide flux, Nat. Geosci., 6, 186-190, https://doi.org/10.1038/NGEO1730, 2013.

Aubinet, M., Grelle, A., Ibrom, A., Rannik, U ., Moncrieff, J., Foken, T., Kowalski, A., Martin, P. H., Berbigier, P., Bernhofer, C., Clement, R., Elbers, J. A., Granier, A., Grunwald, T., Morgenstern, K., Pilegaard, K., Rebmann, C., Snijders,W., Valentini, R., and Vesala, T.: Estimates of the annual net carbon and water exchange of forest: The EUROFLUX methodology, Adv. Ecol. Res., 30, 114-173, 2000.

Aubinet, M., Chermanne, B., Vandenhaute, M., Longdoz, B., Yernaux, M., and Laitat, E.: Long term carbon dioxide exchange above a mixed forest in the Belgian Ardennes, Agr. Forest Meteorol., 108, 293-315, 2001.

Baldocchi, D. D.: Assesing the eddy covariance technique for evaluating carbon dioxide exchange rates of ecosystems: past, present and future, Glob. Change Biol., 9, 479-492, 2003.

Baldocchi, D. D.: Measuring fluxes of trace gases and energy between ecosystems and the atmosphere - the state and future of the eddy covariance method, Glob. Change Biol., 20, 3600-3609, https://doi.org/10.1111/gcb.12649, 2014.

Barr, A. G., Richardson, A. D., Hollinger, D. Y., Papale, D., Arain, M. A., Black, T. A., Bohrer, G., Dragoni, D., Fischer, M. L., Gu, L., Law, B. E., Margolis, H. A., McCaughey, J. H., Munger, J. W., Oechel, W., and Schaeffer, K.: Use of change-point detection for friction-velocity threshold evaluation in eddy-covariance studies, Agr. Forest Meteorol., 171-172, 3145, https://doi.org/10.1016/j.agrformet.2012.11.023, 2013.

Beer, C. H., Reichstein, M., Tomelleri, E., Ciais, P., Jung, M., Carvalhais, N., Rödenbeck, C., Arain, M. A., Baldocchi, D., Bonan, G. B., Bondeau, A., Cescatti, A., Lasslop, G., Lindroth, A., Lomas, M., Luyssaert, S., Margolis, H., Oleson, K. W., Roupsard, O., Veenendaal, E., Viovy, N., Williams, C., Woodward, F. I., and Papale, D.: Terrestrial gross carbon dioxide uptake: Global distribution and covariation with climate, Science, 329, 834-838, 2010.

Berkelhammer, M., Asaf, D., Still, C., Montzka, S., Noone, D., Gupta, M., Provencal, R., Chen, H., and Yakir, D.: 15 Constraining surface carbon fluxes using in situ measurements of carbonyl sulfide and carbon dioxide, Global Biogeochem. Cy., 28, 161179, https://doi.org/10.1002/2013GB004644, 2014.

Billesbach, D. P., Berry, J. A., Seibt, U., Maseyk, K., Torn, M. S., Fischer, M. L., Abu-Naser, M., and Campbell, J. E.: Growing season eddy covariance measurements of carbonyl sulfide and $\mathrm{CO}_{2}$ fluxes: $\mathrm{COS}$ and $\mathrm{CO}_{2}$ relationships in Southern Great Plains winter wheat, Agr. Forest Meteorol., 184, 48-55, https://doi.org/10.1016/j.agrformet.2013.06.007, 2014.

Blonquist Jr., J. M., Montzka, S. A., Munger, J. W., Yakir, D., Desai, A. R., Dragoni, D., Griffis, T. J., Monson, R. K., Scott, R. L., and Bowling, D. R.: The potential of carbonyl sulfide as a proxy for gross primary production at flux tower sites, J. Geophys. Res., 116, G04019, https://doi.org/10.1029/2011JG001723, 2011.

Campbell, J. L., Kesselmeier, J., Yakir, D., Berry, J. A., Peylin, P., Belviso, S., Vesala, T., Maseyk, K., Seibt, U., Chen, H., Whelan, M. E., Hilton, T. W., Montzka, S. A., Berkelhammer, M. B., Lennartz, S. T., Kuai, E., Wohlfahrt, G., Wang, Y., Blake, N. J., and Blake, D. R.: Carbon, climate and carbonyl sulfide, EOS Earth \& Space Science News, 98, https://doi.org/10.1029/2017EO075313, 2017.

Commane, R., Meredith, L. K., Baker, I. T., Berrye, J. A., Munger, J. W., Montzka, S. A., Templer, P. H., Juice, S. M., Zahniser, M. S., and Wofsy, S. C.: Seasonal fluxes of carbonyl sulfide in a midlatitude forest, P. Natl. Acad. Sci. USA, 112, 14162-14167, https://doi.org/10.1073/pnas.1504131112, 2015.

Eugster, W., Zeyer, K., Zeeman, M., Michna, P., Zingg, A., Buchmann, N., and Emmenegger, L.: Methodical study of nitrous oxide eddy covariance measurements using quantum cascade laser spectrometery over a Swiss forest, Biogeosciences, 4, 927-939, https://doi.org/10.5194/bg-4-927-2007, 2007.

FLUXNET: https://fluxnet.ornl.gov/site/14, last access: 19 September 2017.

Foken, T.: The energy balance closure problem: an overview, Ecol. Appl., 18, 1351-1367, https://doi.org/10.1890/06-0922.1, 2008.

Foken, T. and Wichura, B.: Tools for quality assessment of surfacebased flux measurements, Agr. Forest Meteorol., 107, 1-48, 1996.

Friend, A., Arneth, A., Kiang, N., Lomas, M., Ogée, J., Rödenbeck, C., Running, S. W., Santaren, J.-D., Sitch, S., Viovy, N., Woodwards, F. I., and Zaehle, S.: FLUXNET and modelling the global carbon cycle, Glob. Change Biol., 13, 610-633, https://doi.org/10.1111/j.1365-2486.2006.01223.x, 2007.

Goulden, M. L., Munger, J. W., Fan, S.-M., Daube, B. C., and Wofsy, S. C.: Measurements of carbon sequestration by long- 
term eddy covariance: methods and a critical evaluation of accuracy, Glob. Change Biol., 2, 169-182, 1996.

Gu, L., Falge, E. M., Boden, T., Baldocchi, D. D., Black, T. A., Saleska, S. R., Suni, T., Verma, S. B., Vesala, T., Wofsy, S. $\mathrm{C}$., and $\mathrm{Xu}, \mathrm{L} .:$ Objective threshold determination for nighttime eddy flux filtering, Agr. Forest Meteorol., 128, 179-197, https://doi.org/10.1016/j.agrformet.2004.11.006, 2005.

Haslwanter, A., Hammerle, A., and Wohlfahrt, G.: Open- vs. closedpath eddy covariance measurements of the net ecosystem carbon dioxide and water vapour exchange: a long-term perspective, Agr. Forest Meteorol., 149, 291-302, 2009.

Hörtnagl, L. and Wohlfahrt, G.: Methane and nitrous oxide exchange over a managed hay meadow, Biogeosciences, 11, 72197236, https://doi.org/10.5194/bg-11-7219-2014, 2014.

Hsieh, C. I., Katul, G., and Chi, T. W.: An approximate analytical model for footprint estimation of scalar fluxes in thermally stratified atmospheric flows, Adv. Water Resour., 23, 765-772, 2000.

Ibrom, A., Dellwik, E., Flyvbjerg, H., Jensen, N. O., and Pilegaard, K.: Strong low-pass filtering effects on water vapour flux measurements with closed-path eddy correlation systems, Agr. Forest Meteorol., 147, 140-156, https://doi.org/10.1016/j.agrformet.2007.07.007, 2007.

Kaimal, J. C. and Finnigan, J. J.: Atmospheric boundary layer flows: their structure and measurement, Oxford University Press, Oxford, 289 pp., 1994.

Kitz, F., Gerdel, K., Hammerle, A., Laterza, T., Spielmann, F. M., and Wohlfahrt, G.: In situ soil COS exchange of a temperate mountain grassland under simulated drought, Oecologia, 183, 851-860, 2017.

Kroon, P. S., Hensen, A., Jonker, H. J. J., Zahniser, M. S., van't Veen, W. H., and Vermeulen, A. T.: Suitability of quantum cascade laser spectroscopy for $\mathrm{CH}_{4}$ and $\mathrm{N}_{2} \mathrm{O}$ eddy covariance flux measurements, Biogeosciences, 4, 715-728, https://doi.org/10.5194/bg-4-715-2007, 2007.

Langford, B., Acton, W., Ammann, C., Valach, A., and Nemitz, E.: Eddy-covariance data with low signal-to-noise ratio: time-lag determination, uncertainties and limit of detection, Atmos. Meas. Tech., 8, 4197-4213, https://doi.org/10.5194/amt-8-4197-2015, 2015

Lasslop, G., Reichstein, M., Papale, D., Richardson, A., Arneth, A., Barr, A., Stoy, P., and Wohlfahrt, G.: Separation of net ecosystem $\mathrm{CO}_{2}$ exchange into assimilation and respiration using a light response curve approach: critical issues and global evaluation, Glob. Change Biol., 16, 187-208, 2010.

Mahecha, M. D., Reichstein, M., Carvalhais, N., Lasslop, G., Lange, H., Seneviratne, S. I., Vargas, R., Ammann, C., Arain, M. A., Cescatti, A., Janssens, I. A., Migliavacca, M., Montagnani, L., and Richardson, A. D.: Global convergence in the temperature sensitivity of respiration at ecosystem level, Science, 329, 383-840, 2010.

Mammarella, I., Launiainen, S., Gronholm, T., Keronen, P., Pumpanen, J., Rannik, Ü., Vesala, T.: Relative Humidity Effect on the High-Frequency Attenuation of Water Vapor Flux Measured by a Closed-Path Eddy Covariance System, J. Atmos. Ocean. Tech., 26, 1856-1866, 2009.

Mammarella, I., Werle, P., Pihlatie, M., Eugster, W., Haapanala, S., Kiese, R., Markkanen, T., Rannik, Ü., and Vesala, T.: A case study of eddy covariance flux of $\mathrm{N}_{2} \mathrm{O}$ measured within forest ecosystems: quality control and flux error analysis,
Biogeosciences, 7, 427-440, https://doi.org/10.5194/bg-7-4272010, 2010.

Mammarella, I., Peltola, O., Nordbo, A., Järvi, L., and Rannik, Ü.: Quantifying the uncertainty of eddy covariance fluxes due to the use of different software packages and combinations of processing steps in two contrasting ecosystems, Atmos. Meas. Tech., 9, 4915-4933, https://doi.org/10.5194/amt-9-4915-2016, 2016.

Maseyk, K., Berry, J. A., Billesbach, D., Campbell, J. E., Torne, M. S., Zahniser, M., and Seibt, U.: Sources and sinks of carbonyl sulfide in an agricultural field in the Southern Great Plains, P. Natl. Acad. Sci. USA, 111, 9064-9069, https://doi.org/10.1073/pnas.1319132111, 2014.

Massman, W. J.: A simple method for estimating frequency response corrections for eddy covariance systems, Agr. Forest Meteorol., 104, 185-198, https://doi.org/10.1016/S01681923(00)00164-7, 2000.

Massman, W. J. and Lee, X.: Eddy covariance flux corrections and uncertainties in long-term studies of carbon and energy exchanges, Agr. Forest Meteorol., 113, 121-144, 2002.

Mauder, M., Foken, T., Clement, R., Elbers, J. A., Eugster, W., Grünwald, T., Heusinkveld, B., and Kolle, O.: Quality control of CarboEurope flux data - Part 2: Inter-comparison of eddy-covariance software, Biogeosciences, 5, 451-462, https://doi.org/10.5194/bg-5-451-2008, 2008.

McMillen, R. T.: An eddy correlation system with extended applicability to non-simple terrain, Bound.-Lay. Meteorol., 43, 231-245, 1988.

Moncrieff, J. B., Malhi, Y., and Leuning, R.: The propagation of errors in long-term measurements of land-atmosphere fluxes of carbon and water, Glob. Change Biol., 2, 231-240, https://doi.org/10.1111/j.1365-2486.1996.tb00075.x, 1996.

Moncrieff, J. B., Massheder, J. M., de Bruin, H., Ebers, J., Friborg, T., Heusinkveld, B., Kabat, P., Scott, S., Soegaard, H., and Verhoef. A.: A system to measure surface fluxes of momentum, sensible heat, water vapor and carbon dioxide, J. Hydrol., 188189, 589-611, https://doi.org/10.1016/S0022-1694(96)03194-0, 1997.

Monin, A. S. and Obukhov A. M.: Basic laws of turbulent mixing in the surface layer of the atmosphere, Tr. Akad. Nauk. SSSR Geophiz. Inst., 24, 163-187, 1954.

Neftel, A., Ammann, C., Fischer, C., Spirig, C., Conen, F., Emmenegger, L., Tuzson, B., and Wahlen, S.: $\mathrm{N}_{2} \mathrm{O}$ exchange of managed grassland: Application of a quantum cascade laser spectrometer for micrometeorological flux measurements, Agr. Forest Meteorol., 150, 775-785, 2010.

Papale, D., Reichstein, M., Aubinet, M., Canfora, E., Bernhofer, C., Kutsch, W., Longdoz, B., Rambal, S., Valentini, R., Vesala, T., and Yakir, D.: Towards a standardized processing of Net Ecosystem Exchange measured with eddy covariance technique: algorithms and uncertainty estimation, Biogeosciences, 3, 571-583, https://doi.org/10.5194/bg-3-571-2006, 2006.

Peltola, O., Hensen, A., Helfter, C., Belelli Marchesini, L., Bosveld, F. C., van den Bulk, W. C. M., Elbers, J. A., Haapanala, S., Holst, J., Laurila, T., Lindroth, A., Nemitz, E., Röckmann, T., Vermeulen, A. T., and Mammarella, I.: Evaluating the performance of commonly used gas analysers for methane eddy covariance flux measurements: the InGOS intercomparison field experiment, Biogeosciences, 11, 3163-3186, https://doi.org/10.5194/bg-11-3163-2014, 2014. 
Pierce, A. M., Moore, C. W., Wohlfahrt, G., Hörtnagl, L., Kljun, N., and Obrist, D.: Eddy Covariance Flux Measurements of Gaseous Elemental Mercury Using Cavity RingDown Spectroscopy, Environ. Sci. Technol., 49, 1559-1568, https://doi.org/10.1021/es505080z, 2015.

Rannik, Ü., Haapanala, S., Shurpali, N. J., Mammarella, I., Lind, S., Hyvönen, N., Peltola, O., Zahniser, M., Martikainen, P. J., and Vesala, T.: Intercomparison of fast response commercial gas analysers for nitrous oxide flux measurements under field conditions, Biogeosciences, 12, 415-432, https://doi.org/10.5194/bg12-415-2015, 2015.

Rannik, Ü., Peltola, O., and Mammarella, I.: Random uncertainties of flux measurements by the eddy covariance technique, Atmos. Meas. Tech., 9, 5163-5181, https://doi.org/10.5194/amt-9-51632016, 2016.

Reichstein, M., Falge, E., Baldocchi, D., Papale, D., Aubinet, M., Berbigier, P., Bernhofer, C., Buchmann, N., Gilmanov, T., Granier, A., Grünwald, T., Havránková, K., Ilvesniemi, H., Iborjanous, D., Knohl, A., Laurila, T., Lohila, A., Loustau, D., Matteucci, G., Meyers, T., Miglietta, F., Ourcival, J.-M., Pumpanen, J., Rambal, S., Rotenberg, E., Sanz, M., Tenhunen, J., Seufert, G., Vaccari, F., Vesala, T., Yakir, D., and Valentini, R.: On the separation of net ecosystem exchange into assimilation and ecosystem respiration: review and improved algorithm, Glob. Change Biol., 11, 1424-1439, https://doi.org/10.1111/j.13652486.2005.001002.x, 2005.

Sandoval-Soto, L., Stanimirov, M., von Hobe, M., Schmitt, V., Valdes, J., Wild, A., and Kesselmeier, J.: Global uptake of carbonyl sulfide (COS) by terrestrial vegetation: Estimates corrected by deposition velocities normalized to the uptake of carbon dioxide $\left(\mathrm{CO}_{2}\right)$, Biogeosciences, 2, 125-132, https://doi.org/10.5194/bg-2-125-2005, 2005.

Seibt, U., Kesselmeier, J., Sandoval-Soto, L., Kuhn, U., and Berry, J. A.: A kinetic analysis of leaf uptake of COS and its relation to transpiration, photosynthesis and carbon isotope fractionation, Biogeosciences, 7, 333-341, https://doi.org/10.5194/bg-7333-2010, 2010.

Stimler, K., Nelson, D., and Yakir, D.: High precision measurements of atmospheric concentrations and plant exchange rates of carbonyl sulfide using mid-IR quantum cascade laser, Glob. Change Biol., 16, 2496-2503, https://doi.org/10.1111/j.13652486.2009.02088.x, 2010a.

Stimler, K., Montzka, S. A., Berry, J. A., Rudich, Y., and Yakir, D.: Relationships between carbonyl sulfide (COS) and $\mathrm{CO}_{2}$ during leaf gas exchange, New Phytol., 186, 869-878, https://doi.org/10.1111/j.1469-8137.2010.03218.x, 2010b.

Stimler, K., Berry, J. A., Montzka, S. A., and Yakir, D.: Association between Carbonyl Sulfide Uptake and ${ }^{18} \Delta$ during Gas Exchange in $\mathrm{C}_{3}$ and $\mathrm{C}_{4}$ Leaves, Plant Physiol., 157, 509-517, https://doi.org/10.1104/pp.111.176578, 2011.

Sturm, P., Eugster, W., and Knohl, A.: Eddy covariance measurements of $\mathrm{CO}_{2}$ isotopologues with a quantum cascade laser absorption spectrometer, Agr. Forest Meteorol., 152, 73-82, https://doi.org/10.1016/j.agrformet.2011.09.007, 2012.
Webb, E. K., Pearman, G. I., and Leuning R.: Correction of flux measurements for density effects due to heat and water-vapor transfer, Q. J. Roy. Meteor. Soc., 106, 85-100, 1980.

Wehr, R., Commane, R., Munger, J. W., McManus, J. B., Nelson, D. D., Zahniser, M. S., Saleska, S. R., and Wofsy, S. C.: Dynamics of canopy stomatal conductance, transpiration, and evaporation in a temperate deciduous forest, validated by carbonyl sulfide uptake, Biogeosciences, 14, 389-401, https://doi.org/10.5194/bg14-389-2017, 2017.

Werle, P.: Time domain characterization of micrometeorological data based on a two sample variance, Agr. Forest Meteorol., 150, 832-840, https://doi.org/10.1016/j.agrformet.2009.12.007, 2010.

Werle, P.: Accuracy and precision of laser spectrometers for trace gas sensing in the presence of optical fringes and atmospheric turbulence, Appl. Phys. B, 102, 313-329 https://doi.org/10.1007/s00340-010-4165-9, 2011.

Werle, P., Mücke, R., and Slemr, F.: The limits of signal averaging in atmospheric trace-gas monitoring by tunable diode-laser absorption spectroscopy (TDLAS), Appl. Phys. B, 57, 131-139, 1993.

Wienhold, G. F., Welling, M., and Harris, G. W.: Micrometeorological measurement and source region analysis of nitrous oxide fluxes from an agricultural soil, Atmos. Environ., 29, 2219-2227, 1995.

Wohlfahrt, G. and Galvagno, M.: Revisiting the choice of the driving temperature for eddy covariance $\mathrm{CO}_{2}$ flux partitioning, Agr. Forest Meteorol., 237-238, 135-142, https://doi.org/10.1016/j.agrformet.2017.02.012, 2017.

Wohlfahrt, G. and Gu, L.: The many meanings of gross photosynthesis and their implication for photosynthesis research from leaf to globe, Plant Cell Environ., 38, 2500-2507, https://doi.org/10.1111/pce.12569, 2015.

Wohlfahrt, G., Anfang, C., Bahn, M., Haslwanter, A., Newesely, C., Schmitt, M., Drösler, M., Pfadenhauer, J., and Cernusca, A.: Quantifying nighttime ecosystem respiration of a meadow using eddy covariance, chambers and modelling, Agr. Forest Meteorol., 128, 141-162, 2005a.

Wohlfahrt, G., Bahn, M., Haslwanter, A., Newesely, C., and Cernusca, A.: Estimation of daytime ecosystem respiration to determine gross primary production of a mountain meadow, Agr. Forest Meteorol., 130, 13-25, 2005b.

Wohlfahrt, G., Brilli, F., Hörtnagl, L., Xu, X., Bingemer, H., Hansel, A., and Loreto, F.: Carbonyl sulfide (COS) as a tracer for canopy photosynthesis, transpiration and stomatal conductance: potential and limitations, Plant Cell Environ., 35, 657667, https://doi.org/10.1111/j.1365-3040.2011.02451.x, 2012. 